\title{
Pengaruh Pelatihan Dan Disiplin Kerja Terhadap Kinerja Relawan Kantor Badan Penanggulangan Bencana Daerah Kabupaten Ogan Komering Ulu
}

\author{
Darman Syafe'i \\ Fakultas Ekonomi Universitas Baturaja \\ Darmansyafeiumbara@gmail.com
}

\begin{abstract}
This study was to determine the influence of training and work discipline on the performance of volunteers at Regional Disaster Management Agency Office of Ogan Komering Ulu District. The analytical tool used is multiple regression. The results of this study are that simultaneously there is a significant influence between training and work discipline on the performance of volunteers at Regional Disaster Management Agency Office of Ogan Komering Ulu District. Partially the training variable (X1) influences the performance and work discipline (X2) influences the performance. The percentage of the influence of training and work discipline on the performance of volunteers in the Regional Disaster Management Agency Office of Ogan Komering Ulu District was $72.3 \%$ while the remaining $27.7 \%$ was influenced or explained by other variables which are not included in this research model such as work motivation, work environment and leadership (Kasmir, 2016: 189).
\end{abstract}

Keywords: Performance, Training, Work Discipline

\begin{abstract}
Abstrak: Penelitian ini bertujuan untuk mengetahui pengaruh pelatihan dan disiplin kerja terhadap kinerja relawan di Dinas Penanggulangan Bencana Daerah Kabupaten Ogan Komering Ulu. Alat analisis yang digunakan adalah regresi berganda. Hasil dari penelitian ini adalah bahwa secara simultan terdapat pengaruh yang signifikan antara pelatihan dan disiplin kerja terhadap kinerja relawan di Dinas Penanggulangan Bencana Daerah Kabupaten Ogan Komering Ulu. Secara parsial variabel pelatihan (X1) berpengaruh terhadap kinerja dan disiplin kerja (X2) berpengaruh terhadap kinerja. Persentase pengaruh pelatihan dan disiplin kerja terhadap kinerja relawan di Dinas Penanggulangan Bencana Daerah Kabupaten Ogan Komering Ulu sebesar 72,3\% sedangkan sisanya 27,7\% dipengaruhi atau dijelaskan oleh variabel lain yang tidak termasuk dalam model penelitian ini. seperti motivasi kerja, lingkungan kerja dan kepemimpinan (Kasmir, 2016: 189).
\end{abstract}

Kata kunci: kinerja, pelatihan, disiplin kerja

\section{PENDAHULUAN}

Sumber daya manusia merupakan kunci pokok yang harus diperhatikan dengan segala kebutuhannya sehingga harus diatur sebaik mungkin karena sumber daya manusia adalah potensi yang merupakan aset dan fungsi sebagai modal didalam organisasi bisnis yang dapat mewujudkan menjadi potensi nyata secara fisik dan non fisik dalam mewujudkan eksistensi organisasi (perusahaan), oleh karena itu berhasil tidaknya suatu organisasi atau institusi akan ditentukan oleh faktor manusianya atau karyawannya dalam mencapai tujuannya.

Menurut Kasmir (2016:126) pelatihan merupakan proses membentuk dan membekali karyawan dengan menambah keahlian, kemampuan, pengetahuan dan perilakunya. Faktor lain yang dapat mempengaruhi peningkatan kinerja pegawai adalah dengan adanya kedisiplinan seorang karyawan dalam 
menjalankan tugasnya dengan baik. Dilihat dari kepentingan suatu organisasi, disiplin kerja merupakan suatu cara untuk meningkatkan kinerja karyawan demi terciptanya atau terjaminnya kelancaran operasional suatu organisasi. Untuk itu karyawan yang melaksankan tugasnya dengan baik sangat diharapkan supaya pekerjaan yang ditanganinya dapat diselesaikan dengan baik.

Menurut Singodimedjo dalam (Sutrisno, 2009:86), disiplin adalah sikap kesediaan dan kerelaan seseorang untuk mematuhi dan mentaati normanorma peraturan yang berlaku disekitarnya.

Hasibuan (2017:94) kinerja adalah suatu hasil yang dicapai seseorang dalam melaksanakan tugastugas yang dibebankan kepadanya yang didasarkan atas kecakapan, pengalaman, dan kesungguhan serta waktu.

Kinerja karyawan adalah suatu hasil kerja seorang karyawan dalam melaksanakan tugasnya sesuai dengan tanggung jawab yang diberikan kepadanya pada suatu periode waktu tertentu. Kinerja dari suatu organisasi tergantung pada kinerja pegawainya yang dimana setiap pegawai merupakan suatu penggerak bagi berjalannya suatu organisasi.

Dalam menanggulangi bencana daerah dibutuhkan relawan yang handal, ulet, disiplin, terampil dan terpercaya agar organisasi tersebut dapat melaksanakan tugasnya dengan baik. Keberhasilan dari pencapaian tujuan yang diinginkan organisasi yang mendukung diperlukan unsur penting untuk mencapai tujuan tersebut. Dalam menghadapi cuaca yang tidak menentu saat ini, hal ini menjadikan Badan Penanggulan Bencana Daerah harus tetap siaga.

Untuk mengantisipasi terjadinya bencana seperti banjir, longsor maupun kebakaran hutan dan lahan. Untuk mendukung hal tersebut perlu adanya kesiapan manajemen sumber daya manusia, salah satunya adalah kinerja karyawan. Beberapa faktor yang mempengaruhi kinerja karyawan, diantaranya adalah pelatihan dan disiplin kerja.Berdasarkan observasi Petugas relawan kantor Badan Penanggulangan Bencana Daerah Kabupaten Ogan
Komering Ulu, bahwa masih banyak kesalahan dalam penanganan korban yang terkena bencana, hal ini disebabkan karena masih sangat terbatasnya pelatihan yang mereka dapatkan.

Kedisiplinan mempunyai peranan yang sangat penting dalam pelaksanaan kerja relawan. Namun pada kenyataannya relawan pada Badan Penanggulangan Bencana Daerah Kabupaten Ogan Komering Ulu masih sangat banyak relawan yang tidak disiplin dalam berrtugas, hal ini terlihat misalnya saat melaksanakan Presensi kehadiran, masih terlihat karyawan yang memanipulasi kehadirannya yang tidak sesuai dengan kenyataan.

Berdasarkan hal-hal tersebut diatas, peneliti tertarik untuk melakukan penelitian dengan judul “ Pengaruh Pelatihan dan Disiplin Kerja terhadap Kinerja Relawan Pada Kantor Badan Penanggulangan Bencana Daerah Kabupaten Ogan Komering Ulu “.

\subsection{Rumusan Masalah}

Rumusan masalah dalam penelitian ini adalah apakah ada pengaruh pelatihan dan disiplin kerja terhadap kinerja relawan pada kantor badan penanggulangan bencana daerah kabupaten OKU baik secara parsial maupun simultan.

\subsection{Tujuan Penelitian}

Tujuan penelitian ini adalah untuk mengetahui pengaruh pelatihan dan disiplin kerja terhadap kinerja relawan pada kantor Badan Penanggulangan Bencana Daerah Kabupaten Ogan Komering Ulu baik secara parsial maupun simultan.

\section{TINJAUAN PUSTAKA}

\subsection{Pengertian Manajemen Sumber Daya Manusia}

Manajemen Sumber Daya Manusia merupakan suatu perencanaan, pengorganisasian, pengkoordinasian, pelaksanaan, dan pengawasan 


\section{Forum Bisnis Dan Kewirausahaan Jurnal Ilmiah STIE MDP}

terhadap pengadaan, pengembangan, pemberian balas jasa, pengintegrasian, pemeliharaan, dan pemisahan tenaga kerja dalam rangka mencapai tujuan organisasi.

Manajemen sumber daya manusia dapat didefinisikan pula sebagai suatu pengelolaan dan pendayagunaan sumber daya yang ada pada individu (pegawai). Pengelolaan dan pendayagunaan tersebut dikembangkan secara maksimal di dalam dunia kerja untuk mencapai tujuan organisasi dan pengembangan individu pegawai. Mangkunegara, (2015:1)

\subsection{Pengertian Pelatihan}

Kasmir (2016:126) berpendapat bahwa pelatihan merupakan proses membentuk dan membekali karyawan dengan menambah keahlian, kemampuan, pengetahuan dan perilakunya.

Pendapat Andrew E. Sikula dalam (Mangkunegara, 2015:44) mengemukakan bahwa pelatihan adalah suatu proses pendidikan jangka pendek yang menggunakan prosedur, sistematis dan terorganisir dimana pegawai non manajerial mempelajari pengetahuan dan keterampilan teknis dalam tujuan terbatas.

Dengan demikian pelatihan merupakan upaya untuk mengembangkan atau menggali kemampuan yang dimiliki oleh seseorang sehingga memiliki skill, cara berpikir dan perbaikan sikap sesuai dengan yang dibutuhkan oleh suatu perusahaan atau instansi tertentu hingga dapat memecahkan permasalahan yang akan dihadapi dimasa yang akan datang.

\subsection{Indikator Pelatihan}

Program pelatihan karyawan merupakan hal penting sebagai cara meningkatkan kinerja kerja maupun produktivitas.

Indikator-indikator pelatihan karyawan menurut Mangkunegara (2006) diantaranya: Indikator pelatihan menurut Mangkunegara (2015:44), diantaranya:
1. Tujuan Pelatihan

2. Materi.

3. Metode yang digunakan

4. Peserta pelatihan

5. Pelatih (Instruktur)

\subsection{Disiplin Kerja}

Sutrisno (2009:86) disiplin menunjukkan suatu kondisi atau sikap hormat yang ada pada diri karyawan terhadap peraturan dan ketetapan perusahaan. Menurut (Siagian, 2014:305) disiplin merupakan tindakan manajemen untuk mendorong para anggota organisasi memenuhi tuntutan berbagai ketentuan tersebut.

Menurut Hasibuan (2017:193) Kedisiplinan merupakan fungsi operatif MSDM yang terpenting karena semakin baik disiplin karyawan, semakin tinggi kinerja yang dapat dicapainya.

\subsection{Indikator Disiplin Kerja}

Hasibuan, Malayu S.P (2017:194) menjelaskan indikator-indikator disiplin kerja karyawan adalah sebagai berikut:

1. Tujuan dan Kemampuan

2. Teladan Pemimpin

3. Keadilan

4. Waskat

5. Sanksi Hukum

6. Ketegasan

7. Hubungan Kemanusiaan

\subsection{Kinerja}

Kinerja pegawai adalah hasil kerja secara kualitas dan kuantitas yang dicapai oleh seseorang pegawai dalam melaksanakan tugasnya sesuai dengan tanggung jawab yang diberikan kepadanya (Mangkunegara, 67:2015). Kinerja karyawan adalah perilaku nyata yang ditampilkan setiap pegawai sebagai prestasi kerja yang dihasilkan sesuai dengan peranannya dalam perusahaan (Rivai, 2004:309). Kinerja pegawai adalah hasil kerja yang dicapai seseorang berdasarkan persyaratan-persyaratan pekerjaan (Bangun, 2012:231). 
Jadi disimpulkan bahwa Kinerja Pegawai adalah ukuran dalam suatu organisasi sampai sejauh mana kesetiaan karyawan terhadap pekerjaannya serta sampai seberapa besar penghargaan yang diberikan perusahaan dalam rangka pengembangan sumber daya manusia.

\subsection{Indikator Kinerja Pegawai}

Sudarmanto (2014:11) mengemukakan 4 dimensi yang dapat dijadikan tolak ukur dalam menilai kinerja, yaitu:

a. Kualitas, yaitu tingkat kesalahan, kerusakan, dan kecermatan.

b. Kuantitas, yaitu jumlah pekerjaan yang dihasilkan.

c. Penggunaan waktu dalam kerja, yaitu tingkat ketidak hadiran, keterlambatan, dan waktu kerja efektif/jam kerja hilang.

d. Kerjasama dengan orang lain dalam bekerja.

\subsection{Hubungan Pelatihan Dengan Kinerja Pegawai}

Kemajuan perusahaan sangat dipengaruhi oleh kinerja karyawannya setiap perusahaan akan terus berusaha untuk meningkatkan kinerja karyawannya agar dapat mencapai hasil kerja yang baik dan memuaskan. Untuk mencapainya memerlukan banyak usaha yang harus dilakukan, salah satunya dengan mengadakan pelatihan bagi para karyawan dengan demikian dapat meningkatkan kinerja yang dihasilkan.

Pelatihan sebagai usaha untuk meningkatkan kinerja karyawan dalam pekerjaannya sekarang atau dalam pekerjaan lain yang akan dijabatnya segera, Ivancevich dalam (Sutrisno, 2009:67).

\subsection{Hubungan Disiplin Kerja Dengan Kinerja Pegawai}

Menurut Sedarmayanti (2001:65) salah satu faktor yang mempengaruhi kinerja adalah sikap mental (motivasi kerja, disiplin kerja, etika kerja). Sikap mental yang diberikan seorang karyawan akan berpengaruh terhadap kinerjanya. Disiplin kerja merupakan salah satu faktor yang dapat mencerminkan kinerja yang dihasilkan oleh karyawan.

Disiplin kerja adalah salah satu faktor yang sangat mendukung dalam perusahaan/organisasi untuk mencapai tujuannya. Sumber daya manusia yang mempunyai suatu kedisiplinan yang sangat tinggi akan menjadi aset sumber daya manusia sekarang ini.

Dengan adanya kedisiplinan pegawai maka akan menentukan baik buruknya kinerja pegawai itu sendiri, karena pegawai yang disiplin akan selalu memanfaatkan waktunya sebaik mungkin dalam menjalankan pekerjaannya.

\subsection{Penelitian Sebelumnya}

Lilis Suryani (2017) melakukan penelitian dengan judul pengaruh pelatihan dan kedisiplinan terhadap kinerja karyawan pada PT. Cakrawala Citramega Multifinance. Dilakukan dengan analisis regresi linier berganda menemukan bahwa terdapat pengaruh yang signifikan antara pelatihan dan disiplin terhadap kinerja karyawan pada PT. Cakrawala Citramega Multifinance

Ningrum dkk, (2013) melakukan penelitian dengan judul pengaruh Pendidikan dan Pelatihan terhadap kinerja karyawan (karyawan Joint Operating Body Pertamina-PetroChina East Java) dengan analisis regresi linier berganda menemukan bahwa pendidikan dan pelatihan berpengaruh secara signifikan terhadap kinerja karyawan.

Safitri (2013), dalam penelitiannya untuk mengetahui pengaruh pelatihan dan disiplin kerja terhadap kinerja karyawan. Populasi dan sampel sebanyak 38 karyawan pada Dinas Apron Move Control (AMC) PT. Angkasa Pura 1 (Persero) Cabang Bandar Udara Internasional JuandaSurabaya dengan analisis linier berganda. Hasil penelitian menunjukkan pelatihan dan disiplin kerja 
secara simultan berpengaruh positif terhadap kinerja karyawan. Pelatihan tidak berpengaruh signifikan terhadap kinerja karyawan. Disiplin kerja berpengaruh signifikan terhadap kinerja karyawan.

Triasmoko dkk, (2014) dalam penelitiannya untuk mengetahui pengaruh pelatihan kerja terhadap kinerja karyawan. Penelitian pada karyawan PT Pos Indonesia (Persero) Cabang Kota Kediri dengan regresi linier berganda digunakan untuk menghitung atau menjumlahkan pengaruh antara variabel bebas, yaitu Metode Pelatihan (X1), Materi Pelatihan (X2), Instruktur Pelatihan (X3) terhadap variabel terikat Kinerja Karyawan(Y). Hasil penelitian menunjukkan Metode Pelatihan, Materi Pelatihan, Instruktur Pelatihan berpengaruh terhadap kinerja karyawan.

\subsection{Kerangka Pemikiran}

Kerangka pemikiran penelitian ini dapat digambarkan sebagai berikut:

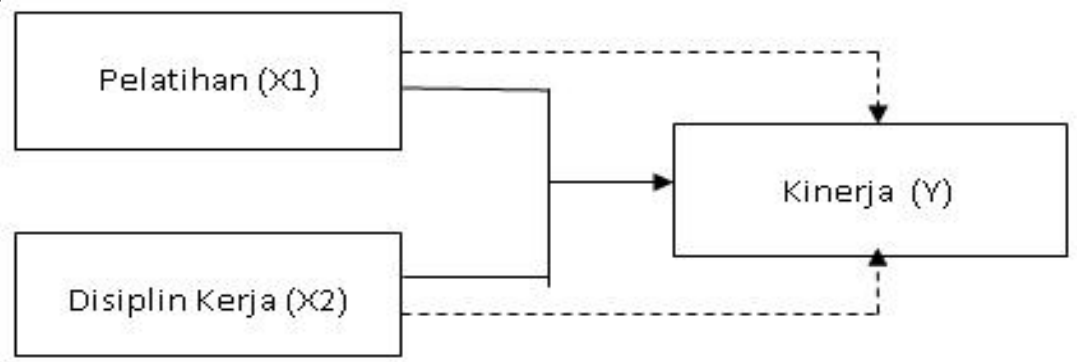

\section{Keterangan : Simultan \\ : Parsial}

Gambar 1. Kerangka Pemikiran

\subsection{Hipotesis}

Hipotesis dalam penelitian ini diduga ada pengaruh Pelatihan dan Disiplin kerja terhadap Kinerja Relawan pada kantor Badan Penanggulangan Bencana Daerah kabupaten Ogan Komring Ulu baik secara parsial maupun simultan.

\section{METODOLOGI PENELITIAN}

\subsection{Ruang Lingkup Penelitian}

Ruang lingkup penelitian ini dilakukan di kantor Badan Penanggulangan Bencana Daerah Kabupaten Ogan Komering Ulu. Variabel yang diteliti yaitu Pelatihan dan disiplin kerja terhadap Kinerja Relawan Badan Penanggulangan Bencana Daerah Kabupaten Ogan Komering Ulu.

\subsection{Data dan Sumber Data}

\subsubsection{Populasi}

Hal - 80
Menurut Arikunto (2010:42) populasi adalah sekumpulan orang atau objek yang memiliki kesamaan dalam satu atau beberapa hal dan membentuk masalah pokok. Pada penelitian Populasi ada jumlah relawan yang ada pada kantor Badan Penanggulangan Bencana Daerah Kabupaten Ogan Komering Ulu berjumlah 67 orang relawan. (BPBD: 2020).

\subsection{Model Analisis}

Analisis yang akan digunakan dalam penelitian ini adalah analisis kuantitatif. Menurut Sugiyono (2008:7) alat analisis yang bersifat kuantitatif adalah alat yang menggunakan data penelitian berupa angka-angka dan analisis menggunakan statistik dan hasil yang disajikan berupa angka-angka yang kemudian diuraikan atau dijelaskan atau diinterprestasikan dalam suatu uraian. Analisis kuantitatif yang digunakan dalam penelitian ini adalah regresi linier berganda.

\subsubsection{Analisis Regresi Linear Berganda}


Alat analisis data yang digunakan adalah analisis regresi linier berganda. Analisis regresi adalah suatu analisis yang mengukur pengaruh antara variabel bebas terhadap variabel terikat. Pengukuran pengaruh antar variabel yang melibatkan lebih dari satu variabel bebas $\left(X_{1}, X_{2}, X_{3, \ldots \ldots \ldots} X_{n}\right)$ dinamakan analisis regresi linear berganda, dikatakan linear karena setiap estimasi atas nilai diharapkan mengalami peningkatan atau penurunan mengikuti garis lurus.

Persamaan estimasi regresi linear berganda adalah sebagai berikut (Sunyoto, 2012:13):

$\mathrm{Y}=\mathrm{a}+\mathrm{b}_{1} \mathrm{X}_{1}+\mathrm{b}_{2} \mathrm{X}_{2}+\mathrm{e}$

Keterangan:

a = nilai konstata

$\mathrm{b}_{1}, \mathrm{~b}_{2}=$ nilai koefisien regresi variabel bebas

$\mathrm{X}_{1}=$ Pelatihan

$$
\begin{array}{ll}
\mathrm{X}_{2} & =\text { Disiplin } \\
\mathrm{Y} & =\text { Kinerja Karyawan } \\
\mathrm{e} & =\text { Error term }
\end{array}
$$

\section{HASIL ANALISIS DAN PEMBAHASAN}

\subsection{Pengujian Instrumen Penelitian}

Sebelum melakukan analisis data terhadap hasil yang diperoleh dari data primer, maka perlu terlebih dahulu dilakukan uji validitas dan uji reliabilitas terhadap instrumen instrumen penelitian.

\subsection{Hasil Uji Validitas}

Hasil dari uji validitas terhadap dua variabel

\begin{tabular}{|c|c|c|c|}
\hline \multicolumn{4}{|l|}{ PELATIHAN (Xl) } \\
\hline Item Pernyataan & r-hitung & r-tabel & Keterangan \\
\hline Item 1 & 0,540 & 0,240 & Valid \\
\hline Item 2 & 0,643 & 0,240 & Valid \\
\hline Item 3 & 0,639 & 0,240 & Valid \\
\hline Item 4 & 0,466 & 0,240 & Valid \\
\hline Item 5 & 0,551 & 0,240 & Valid \\
\hline Item 6 & 0,572 & 0,240 & Valid \\
\hline Item 7 & 0,581 & 0,240 & Valid \\
\hline Item 8 & 0,633 & 0,240 & Valid \\
\hline Item 9 & 0,423 & 0,240 & Valid \\
\hline Item 10 & 0,431 & 0,240 & Valid \\
\hline \multicolumn{4}{|c|}{ DISIPLIN KE RJA (X2) } \\
\hline Item Pernyataan & r-hitung & r-tabel & Keterangan \\
\hline Item 1 & 0,452 & 0,240 & Valid \\
\hline Item 2 & 0,561 & 0,240 & Valid \\
\hline Item 3 & 0,500 & 0,240 & Valid \\
\hline Item 4 & 0,481 & 0,240 & Valid \\
\hline Item 5 & 0,537 & 0,240 & Valid \\
\hline Item 6 & 0,570 & 0,240 & Valid \\
\hline Item 7 & 0,629 & 0,240 & Valid \\
\hline Item 8 & 0,627 & 0,240 & Valid \\
\hline Item 9 & 0,400 & 0,240 & Valid \\
\hline Item 10 & 0,277 & 0,240 & Valid \\
\hline Item 11 & 0,405 & 0,240 & Valid \\
\hline Item 12 & 0,263 & 0,240 & Valid \\
\hline Item 13 & 0,295 & 0,240 & Valid \\
\hline Item 14 & 0,290 & 0,240 & Valid \\
\hline
\end{tabular}
penelitian ini sebagai berikut:

Tabel 1. Hasil Uji Validitas 


\section{Forum Bisnis Dan Kewirausahaan Jurnal Ilmiah STIE MDP}

\begin{tabular}{|c|c|c|c|}
\hline \multicolumn{4}{|l|}{ KINERJA (Y) } \\
\hline Item Pernyataan & r-hitung & r-tabel & Keterangan \\
\hline Item 1 & 0,585 & 0,240 & Valid \\
\hline Item 2 & 0,615 & 0,240 & Valid \\
\hline Item 3 & 0,552 & 0,240 & Valid \\
\hline Item 4 & 0,539 & 0,240 & Valid \\
\hline Item 5 & 0,698 & 0,240 & Valid \\
\hline Item 6 & 0,536 & 0,240 & Valid \\
\hline Item 7 & 0,589 & 0,240 & Valid \\
\hline Item 8 & 0,417 & 0,240 & Valid \\
\hline
\end{tabular}

Sumber: Data Primer, diolah Januari 2020

Berdasarkan hasil uji validitas terhadap 67 responden, diketahui bahwa nilai kofefisien korelasi Product Moment Person r-hitung setiap item pernyataan dari variabel independen lebih besar dari r-tabel sehingga dapat disimpulkan bahwa setiap item pernyataan yang digunakan adalah valid. Artinya seluruh item pernyataan tersebut dapat digunakan dalam penelitian ini.

\subsection{Uji Reliabilitas}

Hasil uji realibilitas untuk masing-masing variabel dapat dilihat pada tabel 2 berikut ini:

Tabel 2. Hasil Uji Reliabilitas

\begin{tabular}{|l|c|c|}
\hline \multicolumn{1}{|c|}{ Variabel } & Koefisien Alpha & Keterangan \\
\hline Pelatihan & 0,844 & Reliabel \\
\hline Disiplin Kerja & 0,811 & Reliabel \\
\hline Kinerja Karyawan & 0,833 & Reliabel \\
\hline
\end{tabular}

Sumber: Data Primer, diolah Januari 2020
Berdasarkan hasil uji reliabilitas yang terlihat dalam tabel diatas dapat disimpulkan bahwa instrumen dalam kuesioner dapat digunakan karena instrumen tersebut diterima (Reliabel).

\subsection{Analisis Regresi Linier Berganda}

Regresi linear berganda adalah model regresi linear dengan melibatkan lebih dari satu variable bebas atau predictor. Dalam bahasa Inggris, istilah ini disebut dengan multiple linear regression.

Regresi Linier Berganda dipakai untuk mengetahui besarnya pengaruh variabel bebas terhadap variabel terikat. Dalam penelitian ini perhitungan analisis regresi linier berganda ini dilakukan dengan menggunakan bantuan program SPSS 23.

Adapun rangkuman hasil perhitungan regresi linear berganda dapat dilihat sebagai berikut:

Tabel 3. Hasil Analisis Regresi Linier Berganda

Coefficients $^{\mathrm{a}}$

\begin{tabular}{|c|c|c|c|c|c|c|c|c|}
\hline \multirow{2}{*}{\multicolumn{2}{|c|}{ Iodel }} & \multicolumn{2}{|c|}{$\begin{array}{l}\text { Unstandardized } \\
\text { Coefficients }\end{array}$} & \multirow{2}{*}{$\begin{array}{c}\begin{array}{c}\text { Standardized } \\
\text { Coefficients }\end{array} \\
\text { Beta }\end{array}$} & \multirow{2}{*}{$\mathbf{T}$} & \multirow{2}{*}{ Sig. } & \multicolumn{2}{|c|}{$\begin{array}{c}\text { Collinearity } \\
\text { Statistics }\end{array}$} \\
\hline & & B & $\begin{array}{l}\text { Std. } \\
\text { Error }\end{array}$ & & & & Tolerance & VIF \\
\hline & (Constant) & 10.561 & 1.608 & & 6.566 & .000 & & \\
\hline & Pelatihan & .628 & .058 & .769 & 10.768 & .000 & .849 & 1.177 \\
\hline & Disiplin Kerja & .122 & .051 & .170 & 2.384 & .020 & .849 & 1.177 \\
\hline
\end{tabular}

a. Dependent Variable: Kinerja

Sumber: Data Primer, diolah Januari 2020 
Didapat persamaan regresi linear berganda sebagai berikut:

$Y=10.561+0.628 X_{1}+0.122 X_{2}$

Persamaan di atas didapat nilai konstanta sebesar 10.561 yang berarti jika variabel Pelatihan $\left(\mathrm{X}_{1}\right)$, dan Disiplin Kerja $\left(\mathrm{X}_{2}\right)$ nilainya nol (tidak ada) maka kinerja karyawan $(\mathrm{Y})$ akan menurun sebesar 10.561. Nilai koefisien regresi Pelatihan $\left(X_{1}\right)$ sebesar 0.628 menyatakan bahwa setiap kenaikan Pelatihan $\left(\mathrm{X}_{1}\right)$ sebesar 1 satuan, maka kinerja karyawan $(\mathrm{Y})$ juga akan mengalami peningkatan sebesar 0.628 dengan asumsi variabel lain tetap. Nilai koefisien regresi Disiplin Kerja $\left(\mathrm{X}_{2}\right)$ sebesar 0.122 menyatakan bahwa setiap kenaikan Disiplin Kerja $\left(\mathrm{X}_{2}\right)$ sebesar 1 satuan, maka kinerja karyawan (Y) juga akan mengalami peningkatan sebesar 0.122 dengan asumsi variabel lain tetap.

\subsection{Pengujian Hipotesis Individual (Uji-t)}

Uji statistik t pada dasarnya menunjukan seberapajauh pengaruh satu variabel penjelas secara individual dalam menerangkan variasi variabel terikat (Kuncoro, 2009:238).

Tabel 4. Hasil T-test

Co efficients $^{\mathrm{a}}$

\begin{tabular}{|l|l|r|r|r|r|r|}
\hline \multirow{2}{*}{ Model } & \multicolumn{2}{|c|}{$\begin{array}{c}\text { Unstandardized } \\
\text { Coefficients }\end{array}$} & $\begin{array}{c}\text { Standardized } \\
\text { Coefficients }\end{array}$ & \multirow{2}{*}{ t } & \multirow{2}{*}{ Sig. } \\
\cline { 2 - 5 } & \multicolumn{1}{|c|}{ B } & Std. Error & \multicolumn{1}{c|}{ Beta } & & \\
\hline \multirow{2}{*}{1} & (Constant) & 10.561 & 1.608 & & 6.566 & .000 \\
\cline { 2 - 7 } & Pelatihan & .628 & .058 & .769 & 10.768 & .000 \\
\cline { 2 - 7 } & Disiplin Kerja & .122 & .051 & .170 & 2.384 & .020 \\
\hline
\end{tabular}

a. Dependent Variable: Kinerja

Sumber: Data Primer, diolah Januari 2020

Berdasarkan hasil pengolahan data yang terdapat pada tabel diatas diperoleh:

1. Nilai t-hitung $X_{1}$ (Pelatihan) sebesar 10.768 dan t-tabel $(\mathrm{df}=\mathrm{n}-\mathrm{k}-1 ; \mathrm{a}=67-2-1 ; 0,025=64)$, maka diperoleh t-tabel sebesar 1,99773 maka $X_{1}$ (Pelatihan) secara signifikan berpengaruh terhadap Y (kinerja karyawan) karena t-hitung lebih besar dari t-tabel yaitu $10.768>1,99773$. Maka dapat dilihat pada gambar di bawah ini:

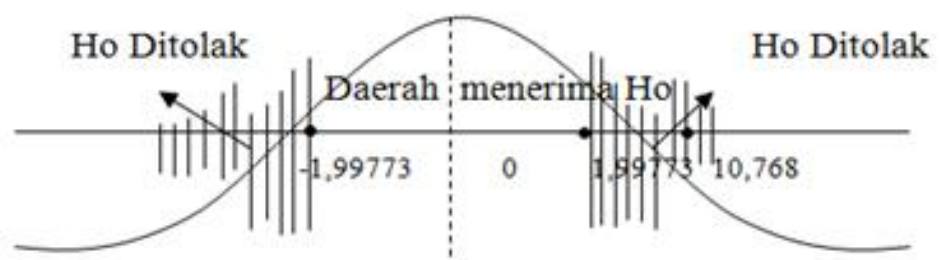

Gambar 2. Daerah Penerimaan Hipotesis Uji-t Variabel Pelatihan $\left(\mathrm{X}_{1}\right)$

2. Nilai t-hitung $X_{2}$ (Disiplin Kerja) sebesar 2.384 dan t-tabel $(\mathrm{df}=\mathrm{n}-\mathrm{k}-1 ; \mathrm{a}=67-2-1 ; 0,025=64)$, maka diperoleh t-tabel sebesar 1,99773 maka $\mathrm{X}_{2}$ (Disiplin Kerja) secara signifikan berpengaruh terhadap Y (kinerja karyawan) karena t-hitung lebih besar dari t-tabel yaitu $2.384>1,99773$. Maka dapat dilihat pada gambar di bawah ini:

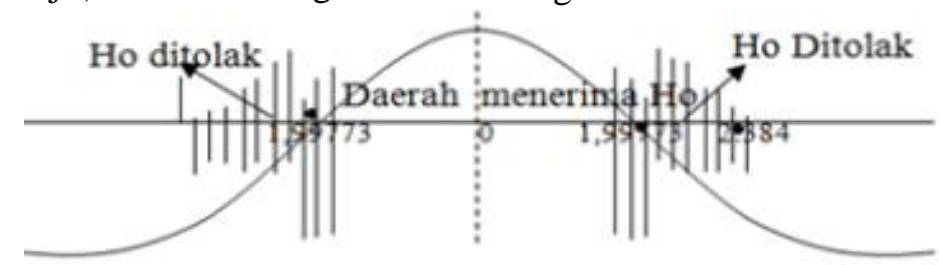

Gambar 3. Daerah Penerimaan Hipotesis Uji-t Variabel Disiplin $\operatorname{Kerja}\left(\mathrm{X}_{2}\right)$ 


\section{Forum Bisnis Dan Kewirausahaan Jurnal Ilmiah STIE MDP}

\subsection{Pengujian Hipotesis Serentak (Uji F)}

Uji ini digunakan untuk mengetahui apakah variabel independen $\left(\mathrm{X}_{1}\right)$ dan $\left(\mathrm{X}_{2}\right)$ secara bersamasama mempengaruhi secara signifikan terhadap variabel dependen $(\mathrm{Y})$. Taraf nyata dari $\mathrm{F}_{\text {tabel }}$ ditentukan dengan derajat bebas $\mathrm{N} 1=(3-1=2)$ dan $\mathrm{N} 2=(67-2-1=64)$ hasil diperoleh untuk F tabel sebesar 3.14 (lihat pada lampiran). Dimana: N1
$=$ pembilang atau $\mathrm{df} 1, \mathrm{~N} 2=$ penyebut atau $\mathrm{df} 2, \mathrm{n}=$ jumlah responden, $\mathrm{k}=$ jumlah variabel independen + dependen. Pengambilan keputusan dilakukan dengan cara membandingkan nilai F-hitung dengan nilai Ftabel yaitu jika, $\mathrm{F}$ hitung $>\mathrm{F}$ tabel artinya diantara variabel independent secara bersama-sama mempunyai pengaruh signifikan terhadap variabel dependen. Hasil perhitungan Uji $F$ dapat dilihat pada tabel berikut:

Tabel 5. Hasil Pengujian Secara Bersama-sama

\begin{tabular}{|l|l|r|r|r|r|r|}
\hline \multicolumn{2}{|c|}{ Model } & $\begin{array}{c}\text { Sum of } \\
\text { Squares }\end{array}$ & \multicolumn{1}{c|}{ Df } & $\begin{array}{c}\text { Mean } \\
\text { Square }\end{array}$ & \multicolumn{1}{c|}{ F } & Sig. \\
\hline \multirow{2}{*}{1} & Regression & 887.932 & 2 & 443.966 & 83.335 & $.000^{3}$ \\
\cline { 2 - 7 } & Residual & 340.961 & 64 & 5.328 & & \\
\cline { 2 - 7 } & Total & 1228.893 & 66 & & & \\
\hline
\end{tabular}

a. Predictors: (Constant), Disiplin Kerja, Pelatihan

b. Dependent Variable: Kinerja

Sumber: Data Primer, diolah Januari 2020

Berdasarkan tabel di atas diperoleh nilai F-hitung 83.335 yang lebih besar dari nilai F-tabel sebesar 3,14 hal ini berarti $\mathrm{F}_{\text {hitung }}>\mathrm{F}_{\text {tabel }}$ sehingga dapat disimpulkan bahwa Pelatihan $\left(\mathrm{X}_{1}\right)$ dan Disiplin
Kerja $\left(\mathrm{X}_{2}\right)$ berpengaruh secara simultan terhadap kinerja Relawan (Y) pada kantor Badan Penanggulangan Bencana Daerah Kabupaten Ogan Komering Ulu.

\section{F-hitung (83.335) > F-tabel (3.14) maka Ho ditolak dan Ha diterima}

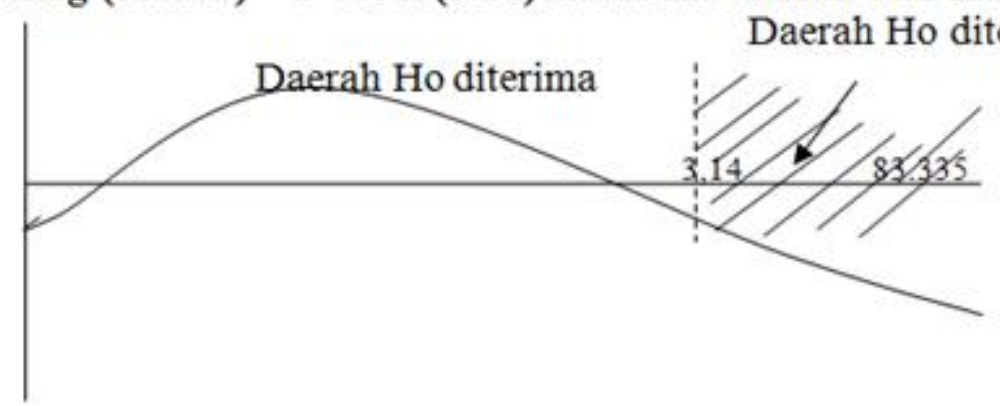

Gambar 4. Daerah Penerimaan Hipotesis Uji-F Variabel Pelatihan $\left(\mathrm{X}_{1}\right)$, dan Disiplin Kerja $\left(\mathrm{X}_{2}\right)$ Terhadap Kinerja (Y)

\subsection{Analisis Koefisien Determinasi $\left(\mathbf{R}^{2}\right)$}

Koefisien determinasi pada regresi linear sering diartikan sebagai seberapa besar kemampuan semua variabel bebas dalam menjelaskan varians dari variabel terikatnya. Hal ini dijelaskan dalam penghitungan analisis regresi sebagai model statistik untuk melihat hubungan antara variabel bebas dantidak bebas. Koefisien determinasi dapat digunakan pada berbagai macam penghitungan statistik. Dalam model regresi, variabel independen memunculkan variabel dependennya. Secara sederhana koefisien determinasi dihitung dengan mengkuadratkan Koefisien Korelasi (R). Hasil uji analisis koefisien determinasi disajikan pada tabel 6 dibawah ini: 


\section{Forum Bisnis Dan Kewirausahaan Jurnal Ilmiah STIE MDP}

Tabel 6. Koefisien Determinasi $\left(\mathrm{R}^{2}\right)$ Model

\begin{tabular}{|c|c|c|c|c|}
\multicolumn{7}{|c}{ Summary $_{\mathrm{b}}$} \\
Model & R & R Square & $\begin{array}{c}\text { Adjusted } \\
\text { R Square }\end{array}$ & $\begin{array}{c}\text { Std. Error } \\
\text { of The } \\
\text { Estimate }\end{array}$ \\
\hline 1 & $.850^{3}$ & .723 & .714 & 2.30814 \\
\hline
\end{tabular}

Sumber: Data Primer, diolah Januari 2020

Berdasarkan tabel di atas diperoleh nilai $R$ Square sebesar 0.723 atau $72,3 \%$. Hal ini menunjukkan bahwa besarnya persentase sumbangan pengaruh pelatihan dan disiplin kerja terhadap naik turunnya kinerja pada kantor Badan Penanggulangan Bencana Daerah Kabupaten Ogan Komering Ulu sebesar $72,3 \%$ sedangkan sisanya sebesar 27,7 \% dipengaruhi atau dijelaskan oleh variabel lain yang tidak dimasukkan dalam model penelitian ini misalnya motivasi kerja, lingkungan kerja dan kepemimpinan (Kasmir, 2016:189).

\subsection{Pembahasan}

Berdasarkan hasil analisis menunjukan bahwa ada pengaruh yang signifikan antara Pelatihan dan Disiplin kerja terhadap Kinerja baik secara parsial maupun simultan terhadap kinerja relawan pada Kantor Badan Penanggulangan Bencana Daerah Kabupaten Ogan Komering Ulu.

Secara umum dari hasil analisis mendukung hipotesis yang menyatakan bahwa pelatihan (X1) mempunyai pengaruh signifikan terhadap kinerja (Y), dan hasil analisis ini akan kuat apabila dihubungkan dengan hasil analisis statistik deskriptif pada deskripsi variabel pelatihan (X1), dimana dalam analisis deskriptif yang dilakukan untuk mengungkapkan penilaian atau klasifikasi pada masing- masing indikator yang terdapat pada masing-masing variabel.

Hasil analisis deskriptif dari semua indikator yang ada dalam variabel pelatihan (X1) mengungkapkan kondisi yang sangat baik, hal ini tergambar pada pencapaian persentase rata-rata diatas $81 \%$, hal ini dapat dilihat pada distribusi jawaban responden tentang indikator tujuan pelatihan dengan pencapaian persentase $88,81 \%$, indikator materi $88,66 \%$, indikator metode yang digunakan $87,76 \%$, indikator peserta pelatihan $87,31 \%$, dan indikator pelatih (instruktur) 85,07\%, dimana hal ini menurut Riduan (2009:23) ada pada tataran kriteria sangat baik. Ini berarti pihak Kantor Badan Penanggulangan Benacana Daerah Kabupaten Ogan Komering Ulu sanagat perlu mempertahankan dan meningkatkan indikator-indikator yang terdapat dalam variabel pelatihan.

Hasil pengelolahan data yang telah peneliti lakukan diperoleh bahwa hasil koefisien t-hitung Pelatihan (X1) sebesar 10,768 dengan t-tabel sebesar 1,99773, maka Pelatihan (X1) secara signifikan berpengaruh terhadap Kinerja (Y), karena t-hitung lebih besar dari t-tabel yaitu 10,768 > 1,99773. Hasil analisis uji t variabel Pelatihan (X1), yaitu menunjukan nilai alpha sebesar $5 \%(0,05)$ dan nilai sig adalah 0,000 . Ternyata nilai sig $<_{\text {alpha }}$ yaitu $0,000<0,05$ maka Ho ditolak dan Ha diterima, artinya ada pengaruh yang signifikan antara Pelatihan terhadap kinerja Relawan pada Kantor Badan Penanggualangan Bencana Daerah Kabupaten Ogan Komering Ulu.

Hal tersebut memiliki makna bahwa dengan mengikuti pelatihan relawan Badan Penanggulangan Bencana Daerah Kabupaten Ogan Komering Ulu dapat meningkatkan kemampuannya untuk menghasilkan kinerja yang maksimal.

Untuk hasil analisis deskriptif dari semua indikator yang ada dalam variabel Disiplin Kerja (X2) mengungkapkan kondisi sangat baik. Hal ini tergambar pada pencapaian persentase diatas $81 \%$, seperti pada indikator tujuan dan kemampuan hasil distribusi jawaban responden mencapai $86,42 \%$, indikator terladan pemimpin hasil distribusi jawaban responden mencapai $85,37 \%$, indikator keadilan mencapai persentase $85,37 \%$ indikator waskat mencapai $84,48 \%$, indikator sanksi hukum mencapai $84,18 \%$, indikator ketegasan mencapai $84,18 \%$, dan indikator hubungan kemanusiaan mencapai $88,66 \%$, dimana hal ini menurut Riduan (2009:23) ada pada tataran kriteria sangat baik. Ini berarti pihak Kantor Badan Penanggulangan Bencana Daerah Kabupaten Ogan Komering Ulu sanagat perlu mempertahankan dan meningkatkan indikator-indikator yang terdapat dalam variabel disiplin kerja. 


\section{Forum Bisnis Dan Kewirausahaan Jurnal Ilmiah STIE MDP}

Hasil pengolahan data diperoleh koefisien t-hitung disiplin kerja (X2) yaitu sebesar 2,384 dengan t-tabel 1,99773, maka disiplin kerja (X2) secara signifikan berpengaruh terhadap kinerja karyawan (Y), karena t-hitung lebih besar dari t-tabel yaitu $2,384>1,99773$. Hasil analisis uji $t$ variabel disisplin kerja (X2), yaitu menunjukan nilai alpha sebesar 5\% $(0,05)$ dan nilai sig adalah 0,000 . Ternyata nilai sig $<_{\text {alpha }}$ yaitu $0,000<0,05$ maka Ho ditolak dan $\mathrm{Ha}$ diterima, artinya ada pengaruh yang signifikan antara disiplin Kerja terhadap kinerja relawan pada Badan Penanggulangan Bencana Daerah Kabupaten Ogan Komering Ulu.

Hal tersebut memiliki makna bahwa jika disiplin kerja ditingkatkan maka dapat menunjang kelancaran segala aktivitas organisasi agar tujuan organisasi dapat dicapai secara maksimal. Hasil penelitian ini sejalan dengan pendapat N. Lilis Suryani (2017) yang melakukan penelitian tentang pengaruh pelatihan dan kedisiplinan terhadap kinerja karyawan pada PT. Cakrawala Citramega Multifinance.

Metode analisis yang digunakan adalah regresi linier berganda. Dari hasil penelitian diperoleh jika pelatihan dan kedisiplinan meningkat, maka kinerja karyawan akan meningkat juga. Berdasarkan uji hipotesis baik sebagian atau simultan, pelatihan dan kedisisplinan berpengaruh secara positif dan signifikan terhadap kinerja pada PT. Cakrawala Citramega Multifinance.

Tetapi berbeda dengan pendapat Erma Safitri (2013) melakukan penelitian tentang pengaruh pelatihan dan disiplin kerja terhadap kinerja karyawan pada Dinas Apron Move Control PT. Angkasa Pura I (Persero) Cabang Bandar Udara Internasional Juanda-Surabaya. Metode analisis yang digunakan adalah uji $\mathrm{t}$, uji $\mathrm{F}$, determinasi dan analisis regresi berganda. Dari hasil penelitian diperoleh bahwa variabel pelatihan berpengaruh tidak signifikan terhadap kinerja karyawan. Sedangkan disiplin kerja berpengaruh signifikan terhadap kinerja karyawan. Sedangkan variabel independen pelatihan dan disiplin kerja terhadap kinerja karyawan secara simultan memiliki pengaruh yang signifikan terhadap kinerja karyawan.
Indikator yang dominan untuk variabel pelatihan (X1) dalam penelitian ini adalah indikator dari tujuan pelatihan yaitu, bertujuan untuk meningkatkan keterampilan kerja agar peserta mampu mencapai kinerja yang maksimal dan meningkatkan pemahaman peserta terhadap etika kerja yang harus diterapkan. Sedangkan indikator yang dominan untuk variabel disiplin kerja (X2) dalam penelitian ini adalah indikator dari hubungan kemanusiaan.

Hubungan kemanusiaan yang harmoni diantara sesama relawan ikut menciptakan kedisiplinan yang baik pada kantor Badan Penanggulangan Bencana Daerah Kabupaten Ogan Komering Ulu.

Hasil analisis statistik deskriptif pada variabel kinerja (Y), memperlihatkan penilaian suatu klasifikasi pada masing-masing indikator sangat baik, hal ini dapat dilihat dari distribusi jawaban responden rata-rata mencapai persentase diatas $81 \%$, seperti indikator kualitas mencapai persentase $83,58 \%$, indikator kuantitas mencapai $86,57 \%$, indikator penggunaan waktu dalam bekerja mencapai $88,21 \%$, indikator kerjasama dengan orang lain mencapai $87,16 \%$, dimana hal ini menurut Riduan (2009:23) ada pada tatanan kriteria sangat baik. Ini berarti pihak Kantor Badan Penanggulangan Benacana Daerah Kabupaten Ogan Komering Ulu sangat perlu mempertahankan dan meningkatkan indikatorindikator yang terdapat dalam variabel kinerja.

Indikator yang paling dominan pada variabel kinerja yaitu indikator penggunaan waktu dalam bekerja yang mencapai $88,21 \%$, dimana definisi dari penggunaan waktu dalam bekerja yaitu seberapa besar tingkat ketidak hadiran, keterlambatan, dan waktu kerja efektif/ jam kerja hilang.

Berdasarkan hasil koefisien nilai F-hitung lebih besar dari nilai F-tabel sebesar 3,14 hal ini berarti $\mathrm{F}_{\text {hitung }}>\mathrm{F}_{\text {tabel }}$ sehingga dapat disimpulkan bahwa pelatihan (X1) dan disiplin kerja (X2) berpengaruh secara simultan terhadap kinerja karyawan (Y) pada Kantor Badan Penanggulangan Bencana Daerah Kabupaten Ogan Komering Ulu. 


\section{Forum Bisnis Dan Kewirausahaan Jurnal Ilmiah STIE MDP}

Untuk mengetahui persentase sumbangan antara variabel pelatihan dan disiplin kerja terhadapkinerja, maka digunakan koefisien determinasi yang didapat besarnya nilai $\mathrm{R}$ Square sebesar 0,723 atau (72,3\%). Hal ini menunjukan bahwa pelatihan dan disiplin kerja berpengaruh terhadap kinerja relawan pada Badan Penanggulangan Bencana Daerah Kabupaten Ogan Komering Ulu sebesar 0,723 atau (72,3\%), sedangkan sisanya sebesar $27,7 \%$ dipengaruhi atau dijelaskan dalam variabel lain yang tidak dimasukan dalam penelitian ini misalnya motivasi kerja, lingkungan kerja dan kepemimpinan (Kasmir, 2016:189).

Berdasarkan hasil kajian hipotesis didapat bahwa pelatihan berpengaruh lebih dominan terhadap kinerja, berdasarkan hal tersebut pelatihan perlu lebih mendapatkan perhatian dibandingkan disiplin kerja. Hal ini ditunjukan dari kontribusi variabel bebas yang paling besar memberikan pengaruh terhadap kinerja relawan.

Indikator tujuan pelatihan, indikator materi, indikator metode yang digunakan, indikator peserta pelatihan dan indikator pelatih (instruktur) merupakan indikator pada variabel pelatihan yang memiliki persentase penilaian yang paling baik bagi relawan terhadap kinerja.

Dengan demikian hak kantor Badan Penanggulangan Bencana Daerah Kabupaten Ogan Komering Ulu seharusnya lebih memperhatikan, mempertahankan dan berupaya meningkatkan pelatihan agar dapat meningkatkan kinerja relawan pada kantor Badan Penanggulangan Bencana Daerah Kabupaten Ogan Komering Ulu.

\section{KESIMPULAN DAN SARAN}

\subsection{Kesimpulan}

Dari hasil analisis dan pembahasan yang telah dilakukan, maka dapat disimpulkan sebagai berikut:

1. Baik secara parsial maupun simultan pelatihan dan disiplin kerja berpengaruh terhadap kinerja relawan pada kantor badan penanggulangan bencana daerah kabupaten ogan komering ulu.

2. Hasil analisis koefisien determinasi ( $R$ Square) sebesar 0,723 dipengaruhi oleh variabel pelatihan dan dan disiplin kerja, hal ini menunjukkan sebesar $72,3 \%$ variabel dari kinerja karyawan dan sisanya sebesar $27,7 \%$ dipengaruhi atau dijelaskan oleh variabel lain yang tidak dimasukkan dalam model penelitian ini misalnya motivasi kerja, lingkungan kerja dan kepemimpinan (Kasmir, 2016:189).

3. Berdasarkan hasil anaslisis bahwa kinerja yang dihasilkan oleh relawan Badan Penanggulangan Bencana Daerah Kabupaten Ogan Komering Ulu sangat kurang dikarenakan pelatihan yang diadakan masih kurang tepat.

4. Hasi analisis dari disiplin kerja menunjukkan bahwa dikantor badan penanggulangan bencana daerah relawan masih sangat kurang mengutamakan kedisiplinan dikarenakan masih menggunakan absensi manual serta kurangnya pengawasan yang dilakukan oleh kepala Badan Penanggulangan Bencana Daerah Kabupaten Ogan Komering Ulu.

\subsection{Saran}

Berdasarkan hasil analisis dan pembahasan yang telah diuraikan pada bab sebelumnya maka peneliti dapat memberikan saran sebagai berikut:

1. Dari hasil analisis, ditemukan bahwa variabel pelatihan dan disiplin kerja memberikan pengaruh yang positif, maka hendaknya kantor badan penanggulangan bencana daerah kabupaten ogan komering ulu agar lebih meningkatkan kualitas pelatihan karyawan agar dapat melakukan kinerja yang lebih baik, Ada baiknya pelaksanaan pelatihan melibatkan tenaga ahli dari perguruan tinggi setempat.

2. Untuk mendapatkan pencapaian kinerja secara maksimal, kiranya kantor badan penanggulangan bencana daerah kabupaten ogan komering ulu lebih memperhatikan kedisiplinan agar dapat 
meningkatkan ketaatan terhadap aturan yang berlaku dikantor tersebut dalam bekerja agar dapat mencapai kinerja yang optimal.

\section{DAFTAR PUSTAKA}

[1] Arikunto, Suharmi. 2010, Prosedur Penelitian Suatu Pendekatan Prakti,. PT. Rineka Cipta, Jakarta.

[2] Bangun, Wilson. 2012, Manajemen Sumber Daya Manusia, Erlangga, Jakarta.

[3] BPBD. 2020, Jumlah Relawan COVID-19 Capai 23.472 Orang, https://bnpb.go.id/ berita/jumlah-relawan-covid19-capai-23-472orang

[4] Denny Triasmoko, Dkk. 2014, Pengaruh Pelatihan Kerja Terhadap Kinerja Karyawan PT. Pos Indonesia (Persero) Cabang Kota Kediri, Jurnal Akademi dan Bisnis, Vol. 12 No. 1.

[5] Danang, Sunyoto. 2012, Manajemen Pemasaran, Buku Seru, Yogyakarta.

[6] Hasibuan. 2017, Manajemen Sumber Daya Manusia, Cetakan 9, PT. Bumi Aksara, Jakarta.

[7] Kasmir. 2016, Manajemen Sumber Daya Manusia (Teori dan Praktik), Edisi 1, Cetakan 2, Rajawali Pers, Jakarta.

[8] Kuncoro, Mudrajad. 2009, Metode Riset Untuk Bisnis dan Ekonomi, Edisi 3, Erlangga, Jakarta.

[9] Mangkunegara. 2015, Manajemen Sumber Daya Manusia Perusahaan, Cetakan Kedua Belas, PT. Remaja Rosdakarya, Bandung.

[10] Ningrum, Widhayu. 2013, Pengaruh Pendidikan dan Pelatihan Terhadap
Kinerja Karyawan (Studi pada Karyawan Joint Operating Body PertaminaPertoChina East Java).

[11] Rivai, Veithzal. 2004, Kepemimpinan dan Perilaku Organisasi, PT. Raja Grafindo Persada, Jakarta.

[12] Riduwan dan Sunarto. 2009, Pengantar Statistika Untuk Penelitian Pendidikan, Sosial, Komunikasi, Ekonomi, dan Bisnis, Alfabeta, Bandung.

[13] Sugiyono. 2008, Metode Penelitian Bisnis, Cetakan Keduabelas, Alfabeta, Bandung.

[14] Sutrisno. 2009, Manajemen Sumber Daya Manusia, Edisi Pertama, Prenadamedia Group, Jakarta.

[15] Suryani. 2017, Pengaruh Pelatihan dan Kedisiplinan Terhadap Kinerja Karyawan pada PT. Cakrawala Citramega Multifinance.

[16] Sedarmayanti. 2001, Sumber Daya Manusia dan Produktivitas Kerja, Bandar Maju, Bandung.

[17] Safitri, Erma. 2013, Pengaruh Pelatihan dan Disiplin Kerja Terhadap Kinerja Karyawan, Jurnal Ilmiah Manajemen Universitas Negeri Surabaya. 1 (4): 10441054.

[18] Sudarmanto. 2014, Kinerja dan Pengembangan Kompetensi Sumber Daya Manusia, Pustaka Pelajar, Yogyakarta.

[19] Suryani, N.Lilis. 2017, Pengaruh Pelatihan dan Kedisiplinan Terhadap Kinerja Karyawan pada PT. Cakrawala Citramega Multifinance, Jurnal Ilmiah Sumber Daya Manusia Vol.1, No.2, Universitas Pamulang. 